\title{
CORRECTIVE ACTION BY THE INTERSTATE COMMERCE COMMISSION
}

\author{
EDWARd H. MILLER*
}

I

\section{INTRODUCTION}

Now pending before the Supreme Court of the United States ${ }^{1}$ is the question whether the Interstate Commerce Commission exceeded its authority in ordering a ro per cent decrease in railway class freight rates for all interstate shipments throughout the United States east of the Rocky Mountains, except for shipments within the northeastern area of the United States, and in ordering a Io per cent increase in railway class freight rates for all interstate shipments within the northeastern area of the United States. The Commission's action was described as an interim measure pending the bringing about of national uniformity in the classification of freight and a greater degree of national uniformity throughout the United States in the class freight rate structures, and was based on findings that these changes were necessary in order to eliminate unreasonableness and undue discrimination in classifications and freight rates, in violation of sections I and 3 of the Interstate Commerce Act. ${ }^{2}$

The order of the Interstate Commerce Commission now challenged in the Supreme Court was entered on May 15, 1945, contemporaneously with the filing of an elaborate $160,000-w o r d$ report or opinion of the Commission explaining and supporting the order. ${ }^{3}$

The Commission's decision is generally regarded as its most important and farreaching action in sixty years, and it is no exaggeration to say that it affects virtually every person in the United States. Although the class rates involved are only a seg-

- A.B. 1938, Washington and Lee University; LL.B. I931, Harvard University. Member of law firm of Cummings, Stanley, Truitt \& Cross, Washington, D. C. Formerly Special Assistant to the Attorney General of the United States, Antitrust Division (1939-1947, except military leave for three years); Special Counsel for Price Administrator and Director of Economic Stabilization in Ex parte I62 (I946); Assistant Attorney General of Missouri (1933-1939). Contributor to legal periodicals, and collaborator in preparation of the Winter, r940, issue of Law and Contentporary Problems (The Sherman Antitrust ACT AND ITS ENFORCEMENT).

${ }^{2}$ October Term, I946, The States of New York, Delaware, et al., Appellants, v. The United States of America, et al., Appellees, No. 343; The Honorable Horace A. Fildreth, Governor of the State of Maine, et al., Appellants, v. The United States of America, et al., Appellees, No. 344; The Atchison, T. \& S. F. Ry., et al., Appellants, v. The United States of America, et al., Appellees, No. 345; appeals from the United States District Court for the Northern District of New York, argued March 3, 4, 5, 1947.

[This paper was prepared before the cases here cited were decided by the Supreme Court. See New York v. United States, 67 Sup. Ct. 1207 (I947), and the Foreword to this symposium. Ed.]

${ }_{24}$ STAT. 379 ( 1887 ), as amended, 49 U. S. C. \$I (I940); 24 STAT. 380 (x887), as amended, 49 U. S. C. $\$ 3(1940)$.

"Class Rate Investigation, I939, 262 I.C.C. 447 (1945); Supplementary report and order denying motions to reconsider and reopen, Class Rate Investigation, I939, $26_{4}$ I.C.C. 4 I (I945). 
ment of all the going railroad ${ }^{4}$ freight rates, they set the pattern for the whole freight rate structure; they move a substantial amount of the high-quality, highrevenue railroad freight; and without classification and class-rate uniformity there is no possibility of achieving uniformity for any other freight rates.

The Commission's decision in 1945 resulted from two separate investigations, instituted on its own motion on July 29, 1939: Docket No. 283ro, entitled Consolidated Freight Classification, and Docket No. 28300 , entitled Class Rate Investigation, 1939. All the railroads in the United States subject to rate regulation were made respondents, and a panel of state commissioners sat with the Commission throughout the proceedings. ${ }^{5}$

The Commission held extensive public hearings in various cities. A record of over seventeen thousand pages was built up. Almost five hundred lawyers and other persons appearing in a representative capacity were participants of record in the proceedings. Pre-hearing conferences started in 1940, hearings were held during I94I, I942, and I943, the case was submitted on extensive oral arguments and numerous briefs in 1944 , and was held under advisement by the Commission for almost a year.

On November 29, x945, nine northern states filed their petition in the District Court for the Northern District of New York to set aside in their entirety the findings and action of the Commission. The governors of the six New England states intervened on the side of the plaintiffs, as did most of the western railroads, which later brought a separate suit in the same court seeking the same relief, this suit being consolidated with the original suit. The Interstate Commerce Commission intervened on the side of the United States, as did the southern states and a number of the western states. An interlocutory injunction was issued by the three-judge court on December 21, I945; the case was tried on its merits in February, I946; and on May 9, r946, the three-judge court filed a unanimous written opinion adopting all the Commission's findings of fact and upholding the action of the Commission in all respects. ${ }^{6}$ In the final decree, however, entered May 27, 1946, the District Court stayed the effect of the Commission's order pending decision by the Supreme Court of the United States, so that the new rates are still inoperative."

\section{II}

\section{Statutory Authority of the Commission}

\section{A. Before I940}

The two investigations instituted by the Commission were inquiries into two kinds of unlawfulness-unreasonableness and discrimination. The unlawfulness

\footnotetext{
- Interstate rail-and-water and all-water rates and classifications were also involved in the investigation orders, but were later eliminated from consideration.

${ }^{5} 24$ STAT. 383 (1887), as amended, 49 U. S. C. $\$ 13(3)$ (1940).

6 State of New York v. United States, 65 F. Supp. 856 (1946).

- The Government and the other appellees tried unsuccessfully in the Supreme Court, by a separate appeal, allowed by Mr. Justice Reed on May 3I, 1946, to have this stay pending appeal vacated by the Supreme Court, on the authority of such cases as Virginian Ry. v. United States, 272 U. S. 658 (1926), and United States v. Ohio, 291 U. S. 644 (1934). United States v. New York, 328 U. S. 824 (1946).
} 
which was the subject of the inquiry concerned classifications and also class rates, each from the standpoint both of unreasonableness and discrimination.

Section $\mathrm{I}(5)(\mathrm{a})$ is the major substantive section of the Interstate Commerce Act dealing with unreasonableness of rates. It provides that "all charges made for any service rendered ... shall be just and reasonable," and it prohibits "every unjust and unreasonable charge." 8 Section $I(6)^{9}$ embodies the same obligations and prohibitions, with respect to classifications, as are imposed by section $I(5)(a)$ in connection with rates. Section $I(4)$ extends these provisions to joint through rates and classifications. ${ }^{10}$

Section 3(I) of the Act deals with discrimination. It mentions neither rates nor classifications, but its language is so broad that it obviously includes both. It prohibits "any undue or unreasonable preference or advantage ... or . . . undue or unreasonable prejudice or disadvantage in any respect whatsoever" to persons, places, or kinds of traffic. ${ }^{11}$ The sweeping character of this prohibition against discrimination-the principal evil aimed at by the original Interstate Commerce Act-has been emphasized by the Supreme Court many times. ${ }^{12}$

Section $I_{5}(\mathrm{I})$ of the Act gives the Commission the power to fix new rates to supplant unlawful rates. ${ }^{13}$ This section provides that upon a finding by the Commission that classifications or rates, or both, are unlawful under section I or section 3, or both sections, "the Commission is hereby authorized and empowered to determine and prescribe what will be the just and reasonable rates, ... maximum or minimum, or maximum and minimum, ... and classification," and it prohibits noncompliance with the new rates and classifications so prescribed. When the Commission prescribes rates under section $I_{5}(\mathrm{I})$, it is, of course, acting in a legislative capacity. ${ }^{14}$

The broad power of the Commission before 1940 is indicated by United States $v$. Chicago, Milwaukee, St. Paul \& Pacific Railroad, in which the Court said:

Under $\S x_{5}$ of the statute the Commission of its own motion may conduct a comprehensive inquiry into the rates of all lines within the area of controversy, may fix the fair relation between one line and another, and may build the structure of the rates accordingly. Florida v. United States, 292 U. S. I; United States v. Louisiana, 290 U. S. $70 .{ }^{15}$

\section{B. The Transportation Act of 1940}

In I940 Congress gave the Commission a clear mandate to deal with interterritorial rate discrimination when it amended section $3(x)$ of the Interstate Commerce Act so as to prohibit specifically any undue or unreasonable preference or advantage to any "region, district, or territory";" and by section $5(\mathrm{~b})$, known as the Ramspeck

\footnotetext{
24 STAT. 379 (I887), as amended, 49 U. S. C. $\$$ I(5)(a) (I940).

${ }_{24}$ Stat. 379 (I887), as amended, 49 U. S. C. $\$$ I (6) (1940).

${ }^{10} 24$ STAT. 379 ( 1887 ), as amended, 49 U. S. C. $5 I$ (4) (I940).

1124 STAT. 380 (I887), as amended, 49 U. S. C. A. \$3(I) (Supp. 1946).

${ }^{12}$ See Louisville \& N. R.R. v. United States, 282 U. S. $74^{\circ}$ (r93I).

${ }^{13} 24$ STAT. 384 (I887), as amended, 49 U. S. C. $\$ 15$ (I) (1940).

16 Terminal R. Ass'n v. United States, 266 U. S. I7 (1924).

${ }^{10} 294$ U. S. 499,509 (1935).

${ }_{10} 24$ STat. 380 (I887), as amended, 49 U. S. C. $\$ 3(r)$ (1940).
} 
Resolution, Congress directed the Commission to institute an investigation of the interterritorial and intraterritorial rates and to remove any unlawful discrimination found to exist between territories. ${ }^{17}$

Until r935 section 3(r) specified only "person, company, firm, corporation, association, locality, or particular description of traffic" as objects of prohibited discrimination. The only word in that series that refers to a geographical unit is "locality." The word "locality" was held not broad enough to include a port district in Texas \& Pacific Railway Company v. United States, ${ }^{18}$ and therefore in 1935 Congress added to this series the following items: "port, port district, gateway, transit point."

These words, especially after the Texas \& Pacific case, seemed not broad enough to cover territories as a whole, a designation which, of course, by r 940 was well recognized as a term of art in the railroad regulation field. The legislative history of the 1940 amendment of section 3(I), which added to the series "region, district, or territory," shows quite clearly that Congress was aware of the limited application of the earlier language and sought to remove this limitation. ${ }^{10}$

The appellants' principal argument in the District Court and in the Supreme Court in the Class Rate case has been that the Commission made a mistake of law in treating the 1940 legislation as a Congressional mandate requiring the Commission to bring about absolute national uniformity in freight rates. The contention is that the Commission is repeating the mistake it made twenty years ago in interpreting the Hoch-Smith Resolution ${ }^{20}$ as a mandate to treat agricultural products as a most favored class, regardless of existing standards of rate making-an erroneous conception which the Supreme Court repudiated in upsetting the Commission's decision. $^{21}$ The fallacy in this argument is that the Commission did not treat the I940 legislation as a mandate to bring about national rate uniformity regardless of differences in territorial conditions, but only as a mandate to investigate territorial conditions, and to eliminate territorial rate differences to the extent that they were found to be unjustified by differences in territorial conditions. Whether the 1940 amendment to section $3(\mathrm{I})$ made a change in substantive law by prohibiting discrimination against territories which was not unlawful before, as the lower court held, or whether the 1940 amendment was merely declaratory, there can be no question about the power of the Commission in 1945 to remove territorial discriminations found to exist. The Commission understood this, and undertook only to remove discriminations which it found to exist. The very point of its whole proceeding was to find out whether existing rate differentials were or were not justified by differences in territorial conditions.

Section 3(I) of the Interstate Commerce Act has always been an unequivocal, although qualified, mandate for rate uniformity. The very thing Congress sought

\footnotetext{
${ }^{27} 24$ STAT. 380 ( 1887 ), as amended, 49 U. S. C., note following $\$ 3$ (1940).

${ }^{18} 289$ U. S. 627 (1933).

${ }^{19} 84$ Cong. Rec. 5889, 9705 (ז939).

2043 Stat. 801 (1925).

21 Ann Arbor R.R. v. United States, 281 U. S. 658 (1930).
} 
to achieve by section $3(\mathrm{I})$, starting in 1887 , was equality of rates. Railroads were required by the original section $3(I)$ to charge equal rates to all persons, and were prohibited from charging them different rates in the absence (and of course, this is the necessary qualification) of different circumstances requiring that they be given different treatment. If two persons under equal circumstances were shipping the same kind of freight from one point to another, they had to be treated equally. Of course, if the freight were of a different kind, or if the mileage or points of origin or destination were different, these or other differences might warrant a rate differentiation; but in the absence of substantial differences of circumstances, the essential mandate of section $3(I)$ will control.

Whereas section $3(I)$ in its inception had been a mandate to the Commission to equalize rates as between persons, it became, in I940, a mandate to equalize rates between regions and territories, subject to the same inherent qualification-a mandate to bring about equality of rates, not regardless of surrounding circumstances, but unless surrounding circumstances require rate differentiations. Before the investigation in the Class Rate case there had never been any effort by the Commission to inquire into the question whether the admitted large differences in class rates between territories were or were not justified or required by comparable territorial differences in costs and other transportation conditions. Neither the Commission nor the Congress, nor anyone else, knew to what extent, if any, these rate differentials were required or justified by different conditions in the several rate territories. However, it was generally believed, as the debates in Congress show, that it would probably be found that at least some of the differences were not justified, or were not justified to the extent of the rate differences. ${ }^{22}$ It was this situation which the Commission recognized as requiring it to bring about "a greater degree" of equalization and uniformity. ${ }^{23}$

\section{III}

\section{The Rate Situation Found by the Commission to Exist in i945}

The existing system of making railroad freight rates has been discussed in detail in other articles in this publication. However, the rate-making situation as the Commission analyzed it in the Class Rate case is so closely related to the relief which the Commission decided to order that an explanation of the phases of the rate structures emphasized by the Commission in its report seems appropriate and necessary here.

\section{A. Classifications}

The first section of the Commission's report is given over to an analysis of the existing classifications. The Commission considered classification to be the foundation or cornerstone of rate making, because rate relationships have no meaning unless they are tied to stable and properly related classification ratings. The class-rate scales

${ }^{22} 84$ CoNG. Rec. 5889-5890, 6071-6072, 9705 (I939); 86 Conc. Rec. 5553 (I940).

${ }^{20} 262$ I.C.C. 447,692 (1945). The Commission's report will be searched in vain for any indication that it considered itself required, as appellants insist it considered itself required, to bring about national rate uniformity regardless of territorial differences in transportation conditions. 
are entirely in terms of class I or first-class ratings. Since all other classification ratings are in terms of percentages of the first-class rates, the actual cost of shipment is just as much affected by the classification rating assigned to a commodity as it is by the level of the first-class rate scale. The Commission's report shows why the Commission instituted not only a class-rate investigation but also a classification investigation, and immediately consolidated the two: because, as a practical matter, class rates cannot be dealt with apart from classifications. As the Commission stated, "A rating must be complemented by a class rate, and vice versa, in order to give substance to either."24

In the early days of railroads, classification of freight was patterned after that used for transportation by boats and wagons and did not follow any definite standards, each road having its own practice. Usually, only a small variety of traffic moved on any one short railroad, which might use only a few simple classes, such as light goods, heavy goods, case goods, logs, and whiskey-a far cry from the modern freight classification containing over 20,000 ratings.

As railroads developed and grew, classification systems became more complex, but not much more unified. For example, at one time in the Middle Atlantic states and West Virginia alone (eastern trunk-line territory) there were $13^{8}$ different freight classification systems. With increasing interchange of traffic between railroads, a number of different classifications were in effect on a single railroad: one for local traffic, another for joint traffic in one direction, another for joint traffic in the opposite direction, and others applying to traffic moving to or from particular sections of the country. Such complexity was, naturally, a source of great confusion and uncertainty to shippers. ${ }^{2 \overline{5}}$ The need for a more nearly uniform classification was acute when the Interstate Commerce Act of 1887 came into being and required that all classifications be reasonable and nondiscriminatory.

Just before the Interstate Commerce Act became effective, the carriers in official territory, ${ }^{26}$ faced with classification systems within their territory at least as chaotic and complicated as the Commission was faced with in 1939 in the nation as a whole, cleaned up and unified the official-territory classification by only eleven days' work, consolidating all the many classification systems in that territory into one new one, which became effective with the Act on April r, 1887.27

Since Congress and the Interstate Commerce Commission were and are dealing with a national economy rather than a regional economy, it was naturally to be expected that under the direction of the Commission national classification uniformity would quickly follow the enactment of the Interstate Commerce Act in 1887 , especially after the experience of the eastern carriers in their quick cleaning up of the classifications in their territory. However, although the Commission has constantly

\footnotetext{
24262 I.C.C. 447,473 (1945).

25 Suspension of Western Classification, 25 I.C.C. 442 (1912).

${ }^{20}$ Roughly, the area of the United States north of the Potomac and Ohio rivers, and east of the Mississippi River.

${ }_{27} 2$ I.C.C. ANN. REP. $36-37$ ( 1888 ).
} 
emphasized the necessity of national classification uniformity, the differences between the classifications of the East, South, and West are almost as fundamental and varied as they were in 1887 , and the Commission had never undertaken to tackle the problem of national classification uniformity until 1939.

The Commission, prior to I939, had brought about classification uniformity within the separate regions, step by step, but had not tried to deal with the problem of the relationship between regions. These region-by-region adjustments, which, like the national investigation, dealt with both classifications and class rates in the same proceedings, were accomplished during the I920's and early I930's. ${ }^{28}$

In the Consolidated Southwestern Cases the Commission made this rather plaintive progress report:

For years we have endeavored to promote uniformity in classification. Except for unification of rules and commodity descriptions, the progress in that direction has not been encouraging. ... So long as vital differences in classification exist it is impossible to.bring about uniform class percentages throughout the country, but, on the other hand, until the class percentages are made more nearly uniform, progress toward uniform classification is impeded. ${ }^{29}$

In 1939 there were three major classifications, just as there had been in 1887 . The differences between them, and their relationship to each other, are illustrated in the following table (which also includes the separate Illinois classification, a further complication):

TABLE $x^{30}$

\begin{tabular}{|c|c|c|c|c|c|}
\hline \multirow[b]{3}{*}{ Percent of Class 100} & \multicolumn{5}{|c|}{ Regular Claass Designation } \\
\hline & \multirow[b]{2}{*}{ Official } & \multirow[b]{2}{*}{ Illinois } & \multirow[b]{2}{*}{ Southern } & \multicolumn{2}{|c|}{ WESTERN } \\
\hline & & & & $\begin{array}{c}\text { Western } \\
\text { Trunk-Line and } \\
\text { Southwestern } \\
\text { Territories }\end{array}$ & $\begin{array}{l}\text { Mountain- } \\
\text { Pacific } \\
\text { Territory }\end{array}$ \\
\hline 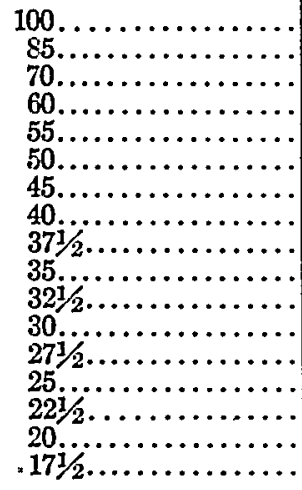 & $\begin{array}{c}1 \\
2 \\
3 \\
\mathbb{R}-26 \\
4 \\
\cdots \\
\cdots \\
\dddot{5} \\
\cdots \\
\dddot{6} \\
\ldots \\
\ldots \\
\cdots\end{array}$ & $\begin{array}{c}1 \\
2 \\
3 \\
\mathbb{R}-2 \dot{6} \\
4 \\
\dddot{A} \\
\dddot{5} \\
\mathbb{B} \\
\dddot{0} \\
\dddot{\mathrm{C}} \\
\dddot{\mathrm{D}} \\
\mathbb{\mathrm { I }} \\
\ldots\end{array}$ & $\begin{array}{c}1 \\
2 \\
3 \\
\dddot{4} \\
\dddot{5} \\
6 \\
\dddot{7} \\
\dddot{8} \\
\dddot{9} \\
10 \\
11 \\
12\end{array}$ & $\begin{array}{c}1 \\
2 \\
3 \\
\dddot{4} \\
\dddot{A} \\
\dddot{5} \\
\dddot{B} \\
\mathrm{C} \\
\dddot{\cdots} \\
\dddot{D} \\
\dddot{\mathrm{E}}\end{array}$ & $\begin{array}{c}1 \\
2 \\
3 \\
4 \\
\dddot{5}, \mathrm{~A} \\
\dddot{\mathrm{B}} \\
\cdots \\
\cdots \\
\dddot{\mathrm{C}} \\
\dddot{\mathrm{D}} \\
\dddot{\mathrm{E}} \\
\cdots\end{array}$ \\
\hline
\end{tabular}

${ }^{29}$ Southern Class Rate Investigation, roo I.C.C. 513 (1925); Consolidated Southwestern Cases, 123 I.C.C. 203 (1927); Western Trunk-Line Class Rates, I64 I.C.C. I (1930); Eastern Class Rate Investigation, I64 I.C.C. 314 (1930).

${ }_{30} 123$ I.C.C. 203,398 (1927). so 262 I.C.C. 447,467 (1945). 
In 1942, as of August 3, there were 20,916 sets of ratings in effect. Approximately one-third of the carload ratings were uniform in the three classifications, but all the rest of the carload ratings represented differences between territories, and almost onefourth of all the carload ratings were unlike in any two of the classifications.

The ratings are subject to numerous other substantial variations, inconsistencies, and disparities. The great bulk of the items are concentrated in a comparatively few classes, and some classes contain no items at all, or only one, two, or three items. The range of the variations is wide. For example, in carload ratings, on items rated class 35 in official territory, the ratings in southern and western territories range from class $17 \frac{1}{2}$ to 55 ; on items rated class 40 in southern, the ratings in official range from class $27^{1 / 2}$ to 70 , and in western, from class $171 / 2$ to 40 ; and on items rated class 45 in western, the ratings in official range from class $271 / 2$ to 85 , and in southern, from class 30 to 55 .

There is no consistency in the assignment of ratings on the same article as between less-than-carload lots and carloads. On a given item, one classification will provide the same rating for less-carloads as for carloads, but in other classifications the ratings for carloads will be lower (or perhaps higher) than for less-carloads. Although less-carload and carload ratings are the same on many items, on the great majority of them the former are higher than the latter and extremely wide spreads often occur, with less-carload ratings ranging up to $47 \mathrm{I}$ per cent of carload ratings. Frequently these differences show up much more in the rates than in the ratings, because even when the ratings are the same in all three territories the rates are subject to the differing rate levels.

Of course, the real problem which results from different territorial classifications lies in the making of interterritorial rates, where different classification ratings compound the difficulty caused by different rate levels. Not only are the rate levels different and the articles assigned to different classes; the classes frequently have different identification symbols, or the same identification symbol represents classes having different percentage relationships to first class or to other classes. Sometimes a direct route goes through all three classification territories. Thus, different rates exist in opposite directions between the same points, and over the same routes, on classes that do not bear like percentage relations to the corresponding first-class rates between the territories concerned. There is no way, except through classification and class-rate uniformity, to relieve this situation, because an attempt to do it by changing the classification of a particular article for the purpose of an interterritorial movement distorts the rates as the distance in one of the territories increases and the distance in the other territory, which has a different rate level, decreases. ${ }^{31}$

The Commission concluded that there was no reason, of any validity, for the sixty-year delay in bringing about classification uniformity. The Commission concluded that necessary specific adjustments in rates could always be made by adjusting rate levels or by making exceptions to the classification, and that there was never

${ }^{31}$ State of Alabama v. New York Central R.R., 235 I.C.C. 255 (1939), 237 I.C.C. 515 (1940). 
any necessity for having different classification ratings for the same article. The Commission pointed out that if the same classification rating can apply in a single area including regions as dissimilar as Maine and southern Illinois in official territory, or Florida and Kentucky in southern territory, there is no reason why the same classification cannot apply throughout the United States. The Commission gave the railroads the opportunity to take the initiative in preparing a new uniform classification, and they have indicated that they will do so, although unfortunately no time limit was set. This commitment of the railroads does not, of course, make classifcations less important in the case now before the Supreme Court. The classification findings of the Commission are still important, both because of the interdependence of classifications and class rates and because the classification findings as well as the class-rate findings are embodied in the Commission's single report, which is under attack in its entirety and which seems indivisible.

\section{B. Class-Rate Structures}

As explained above, neither the classification alone nor the class rate alone determines the cost of shipment, and classification uniformity within territories has gone hand in hand with class-rate uniformity within territories in the Commission's regional proceedings. The territorial class-rate structures are at least as far out of line with one another as the territorial classifications.

The railroad freight-rate structure of the United States has developed on a localized basis like a patchwork quilt, with each locality or railroad starting with a different level and scheme of rates. The localities and railroads have grown and merged into fewer levels and schemes, until the present territorial boundaries were finally reached. But the crossing of these boundaries to achieve national uniformity had to wait until 1947; before the Class Rate Investigation was started in 1939 the Commission had made no attempt to harmonize or relate the regional rate structures.

There are, of course, five rate territories, compared with three classification territories, and these five rate territories are further divided into various zones and subterritories with different schemes of rates. In the Eastern Class Rate Investigation the Commission noted that rates in the three traditional subdivisions of official territory "have grown up independently of each other and, for the most part, with little common resemblance," with some of their class rates "difficult to describe because they are not based upon any definite principle."32

In the South, the class-rate structure prior to I 928 was a hodgepodge of rates built around the old basing-point system, and the Commission in describing the rate structure of southern territory prior to the southern revision said that "great inconsistencies prevail." 33 The rates in the West had likewise evolved piecemeal and had been the subject of complaints by every state regulatory commission in the territory. ${ }^{34}$

The Commission in the regional proceedings did set up uniform scales of class

\footnotetext{
${ }^{32} 164$ I.C.C. at 323,332 (1930).

${ }^{33}$ Southern Class Rate Investigation, xoo I.C.C. at 532 (1925).

3* Western Trunk Line Class Rates, I64 I.C.C. $1,26-36$ (I930).
} 
rates for each region, but provided special different treatment for the sub-regions and for particular situations. Key-point rates were provided to supplant class rates in parts of each territory, but the key-point rate systems of the territories, like the classrate systems, were not consistent or similarly extensive within the separate territories. In the border areas between territories efforts were made, through special rate adjustments, to soften the sharp breaks at the borders between the territorial rate levels. ${ }^{35}$ In the West, four separate zones were set up, with an elaborate laminated formula for adding zone differentials layer on layer in making rates between zones. ${ }^{30}$

The interterritorial class rates (as distinguished from the intraterritorial class rates described above) were far more complicated, even after the regional revisions, and are still unsuitable to move traffic in a national flow. It is only necessary to study the $\mathrm{K}-2-\mathrm{Q}-\mathrm{I}$ rate scheme applicable between southern territory and the western part of official territory, ${ }^{37}$ or the complexities of the interterritorial rate adjustment covering the border area on both sides of the boundary between official and southern territories, ${ }^{38}$ to discover how unnecessarily complex and difficult the interterritorial rate situation has been made by the fact that each territory has its separate classification and class-rate structure. If any further persuasion is necessary, it is suggested that the complications caused by the Mississippi River boundary between the West and the other territories be examined. ${ }^{39}$

\section{IV}

\section{The Frndings and Conclusions of the Commission}

The proceedings before the Commission in the Class Rate case were characterized by the usual informality, in comparison with a court of law, as far as rules of evidence and latitude in method and scope of presentation are concerned. As a result; a substantial part of the record is made up of statements by various shipping and other interests of their positions and views, which were not in all cases supported by detailed or relevant factual data. However, the 17,000 -page record does have detailed factual evidence covering almost every kind of rate situation, and the Commission itself caused to be prepared and received in evidence elaborate technical studies, perhaps the most important of which were the cost, traffic, and economic studies. The original report of the Commission is over 160,000 words long, and is highly technical and rather discursive. However, the major findings and conclusions can be reduced to six main propositions, which will be analyzed separately below. Whether these six major findings were supported by adequate evidence and preliminary findings is the most important issue in the case before the Supreme Court. In (1935).

${ }^{35}$ See, for example, North Carolina Corporation Comm'n v. Akron, C. \& Y. Ry., 213 1.C.C. 259

${ }^{30}$ Western Trunk Line Class Rates, I64 I.C.C. I (1930), 204 I.C.C. 595 (I934).

${ }^{37}$ Southern Class Rate Investigation, 100 I.C.C. 513, 532 (1925).

${ }^{23}$ North Carolina Corporation Comm'n v. Akron, C. \& Y. Ry., 213 I.C.C. 259 (1935); Commonwealth of Kentucky v. Ahnapee \& W. Ry., 213 I.C.C. 297 (1935).

${ }^{39}$ Western Trunk Line Class Rates, 164 I.C.C. I (1930); Western-Southern Class Rates, 226 I.C.C. 497 (1938); Consolidated Southwestern Cases, 2rst Supplemental Report, 205 I.C.C. 6or (1934). 
a sense it is the only real issue in connection with the I940 legislation, because, as noted above, the difference between the parties is really not whether Congress gave the Commission a mandate to equalize rates regardless of territorial transportation conditions, but is rather whether, or the extent to which, territorial transportation conditions are sufficiently different to warrant the existing territorial rate differentials.

x. Class rates within southern and western territories, and from these territories to official territory, are much higher, article for article, than the rates within official territory.

The Commission first considered the territorial rate levels as distinguished from specific situations involving competitive rate inequalities. It concluded that the firstclass rate scale for southern territory was 37.7 per cent higher than the official territory first-class rate scale, and that the three rate territories in the West had first-class rate scales higher than the official scale by $46,6 \mathrm{r}$, and $7 \mathrm{I}$ per cent, respectively. These are the figures for intraterritorial movements.

Because interterritorial movements can be figured only in terms of specific places (the actual rate depending upon how much of the movement is in each territory), abstract comparisons of interterritorial rate levels with intraterritorial rate levels cannot be made. The Commission found that a Nashville shipper would pay 39 cents more on each hundred pounds of first-class freight moving to Indianapolis, Indiana, than a shipper to Indianapolis from Kent, Ohio (the distance being practically the same) -a disadvantage of $4 \mathrm{I}$ per cent. Thousands of such examples were offered in evidence.

Comparisons such as this are, of course, theoretical, and based on the published rate scales and tariffs, without regard to actual shipments. Having considered these discriminatory rate levels, the Commission went on to consider the testimony of shippers who were discriminated against, and to hear about their actual experiences of competitive disadvantages caused by the discriminatory rates, of which the following incidents are illustrative:

Atlanta, Georgia, is a large producer of machinery-wiping rags, which were in heavy demand in official territory in carload lots during the war, but the Atlanta shipper competing in official territory with official-territory shippers was obliged to pay rates 80 per cent higher than the official-territory level. The Atlanta producers were consistently unsuccessful in bidding for business in official territory, solely because of this freight-rate discrimination.

An extreme case was that of a manufacturer of automobile truck bodies at Nashville, Tennessee, who labored under a rate handicap as high as 253 per cent of the rates available to his competitor at Detroit, Michigan, when both manufacturers were shipping to Metuchen, New Jersey, which is 965 miles from Nashville and 616 miles from Detroit. The Nashville shipper was paying \$2.Io per hundred pounds, and the Detroit shipper from 53 cents to $\$ 1.03$.

A large iron and steel company in Pueblo, Colorado, was able to reach eastward only as far as 700 miles, compared with its distribution in all other directions of 
I,000 to $\mathrm{I}, 600$ miles. The controlling factor in preventing more extensive distribution in the East was the class-rate structure, which permitted Pittsburgh to ship $5^{\circ}$ per cent farther for the same charge than Pueblo. For example, Pueblo was paying $\$ 1.05$ to ship steel shell castings 6or miles to Omaha, Nebraska, whereas Pittsburgh was shipping to Omaha, 922 miles away, for only 99 cents.

2. Higher class rates have impeded the development and movement of class-rate traffic within southern and western territories, and from these territories to official territory, and thus have made all the class-rate structures obsolete.

a. Impeding the development of class-rate traffic-economic data. The Commission, having found class rates higher in the South and West, and having found that these discriminations were injuring individual shippers, properly considered that in investigating territorial discrimination, it should inquire further into economic disadvantages of the South and West on a territorial basis, because territorial discrimination would seem to mean something broader than discrimination against individual shippers located in a territory. If the territorial rate levels in the South and West were substantially higher than the official-territory level, and if the industrial development of the South and West had been retarded, so that these regions were at substantial economic disadvantages, it was a legitimate inference that there existed at least some cause and effect relationship between these two facts. Elaborate economic data were introduced in evidence by the Commission's experts and by others, on the basis both of logic and precedent. ${ }^{40}$

The evidence showed that in 1939 official territory produced 67.8 per cent of all the manufactured products in the United States, by value, and $7 \mathrm{r} .4$ per cent of the total value added by manufacture. The average dollar income per person employed in $x 940$ in official territory was $\$ \mathrm{r}, 988$, compared with $\$ 94^{\circ}$ in southern territory and $\$ 1, I 77$ in southwestern territory.

The South and West furnish raw materials to official territory, which adds intensively to their values by making finished products, which it then ships back to the South and West. This dominant mercantile position is achieved largely through the imposition of larger rate discriminations on manufactured goods than on raw materials. For example, on cottonseed oil the rate from southern to official territory is only 7 per cent higher than the official-territory rate, but the rate on cottonseed oil manufactured into oleomargarine is 35 per cent higher. A striking illustration of the way in which the rates have discouraged manufacturing in the South and West is afforded by the fact that the average ton of outbound freight from official territory represents value added by manufacture of $\$ 54.69$, which is about thirteen times as great as the $\$ 4.19$ value added by manufacture to the average ton outbound from the South and West.

The South and West are largely dependent on official territory for new manufacturing industries, because a substantial portion of the purchasing power of the United States is in official territory, which has approximately half of the population of the

4 Texas \& P. Ry. v. Interstate Commerce Commission, I62 U. S. 197, at 219 (1896). 
United States, 64 per cent of the national market for all goods and services, and $7^{6}$ per cent of the market for industrial machinery and raw materials.

The Commission concluded that piecemeal adjustment of class rates could never adequately meet the problem of the lack of development of class-rate traffic from the South and West, because individual adjustments do not and cannot take into account traffic which does not already exist. The Commission concluded that class rates presently discriminate against the southern and western industries that use and pay them; they also discriminate against the industries in existence which would use them if they were not so high; but they go even farther, and discriminate against industries that are still unborn and that cannot be born until fair class rates precede them into existence.

b. Non-use or obsolescence of class rates. The Commission found that the class rates have, by reason of nonuse, become obsolete, and that they "do not now serve the purposes for which they were designed." ${ }^{\text {II }}$

In the Southern Class Rate Investigation the Commission said:

The new class rates should look also to the future. They should, for example, be so framed as to facilitate the elimination not only of special classification exceptions but also of many commodity rates which provoke complaints of discrimination and have no other excuse than an inadequate and imperfect class-rate structure. ${ }^{42}$

A waybill study was introduced in evidence showing on a sample basis how much carload traffic moved on class rates in 1942. It showed that in official territory 5.8 per cent of the carload traffic moved on class rates, but that only 1.8 per cent of such traffic moved on class rates within southern territory, 2.4 per cent within southwestern territory, and 0.6 per cent in western trunk-line territory. All the rest of the traffic in these territories moved on exception or commodity rates. The evidence showed wholesale removals of commodities from the classifications, over three thousand commodities having been removed from the southern classification at one time in September, r940.

The class rates are the pattern and heart of any rate structure. The Commission concluded that if the class rates in the South and West were so high that exception rates and commodity rates could, in the short space of time since the regional classrate revisions, supersede them almost completely, there was something fundamentally wrong with these class-rate structures. When class rates become obsolete, the hodgepodge that emerges, made up almost entirely of ad hoc rate adjustments, cannot accurately be called a coherent rate structure. The conversion by the carriers of class rates into paper rates, after the extensive labors of the Commission in setting up the regional class-rate structures, proves that the regional class rates have become obsolete, largely by virtue of their maladjustment, region by region, with each other. The Commission concluded that this excessive use of ad hoc rates had broken down the soundness of the rate structures, and made the class rates so obsolescent or obso-

$\triangle 1$ Class Rate Investigation, 1939, 262 I.C.C. 699 (1945).

${ }^{12}$ I00 I.C.C. 513,603 (1925). See also Consolidated Southwestern Cases, I23 I.C.C. 203, 234 (I927). 
lete that they required revision, because they would not and could not move the traffic which they were designed to move, and because each rate structure had almost completely broken away from what was intended to be its pattern and cornerstone.

3. Comparative costs of transportation service do not justify the existing classrate differentials.

The most important factor in comparing territorial transportation conditions is cost of service, because practically all other factors, such as density of traffic, terminal operations, terrain, etc., are merged in the cost figures. The Commission relied heavily on the cost study introduced in evidence by one of its experts, Dr. Ford K. Edwards, which has been called the most comprehensive study of transportation costs ever made. Space limitations prevent any detailed explanation of this cost evidence, but the procedure followed was to relate every expense of every railroad in each territory to the particular units of service with which each item of expense was found to be directly variable (such as gross ton-miles, car miles, car days, etc.), and then, knowing the number of each unit furnished in each territory, to construct cost scales for every possible significant variation of equipment, loading, etc. From the cost scales it was then possible to determine costs in each territory of representative identical loads and hauls, and of actual loads, hauls, and traffic consists. Almost every possible kind of territorial comparison was made, using both direct or variable costs and fully distributed costs, including allowances for return, with the result that the Commission concluded that no substantial difference could be found to exist between the territories in transportation costs, costs in the South being slightly below those in official territory, and costs in the West being, in general, slightly higher. The Commission therefore found that existing territorial rate differentials are not justified by territorial cost differentials. Rates of return in the South and West were found by the Commission to be more favorable than in official territory, and this was stated to be an additional reason for the conclusion that the rate differentials were not justified.

4. Differing consists and volumes of traffic within the territories are no justification for the class-rate differentials.

Although there is more class-rate traffic in official territory than in other territories, and although many commodities move in larger volume in one territory than in another, the Commission found that there were not sufficient differences in consists . for revenue purposes to justify the class-rate differentials.

In the first place, all interterritorial traffic is common to two or more territories. In the second place, the high-paying traffic, embraced mainly in the Commission's grouping called "Manufactures and Miscellaneous," accounts for 27 to 29 per cent of the total tons carried in each of the three territories-a small spread. The corresponding revenue percentages differ by similarly small margins. The three remaining principal groups of products, which can broadly be characterized as traffic moving at relatively low rates and in substantial volume, likewise have a narrow spread as between territories, of under 4 per cent at the extremes, in both total tons carried 
and revenues, so that when considered by groups the consists of the territories do not differ very much.

On the question whether there should be rate differences because a particular commodity moves in great volume in one territory and in small volume or not at all in another territory, the answer is that territorial volume means nothing to the individual shipper, and nothing to the carrier except from the standpoint of costs, which, territory by territory, were found not to differ substantially. The real question is not whether the commodities moving in the several territories are different, but whether they have different rate-bearing characteristics. The fact that some particular commodity moves regularly in substantial quantity in one territory-like phosphate rock in the South, which moves only in small quantities in the other territories-means nothing if comparisons of total revenues and rates of return show that other commodities must be moving in the other territories with equal revenueproducing effects.

\section{Equalizing the class rates of the territories is not dependent on equalizing other rates.}

Appellants in the Class Rate case claimed that the exception and commodity rates in the South and West were lower for the same freight than the official territory rates, and that the Commission could not properly raise class rates in official territory and lower them in other territories without, at the same time, bringing about some kind of equalization of exception and commodity rates, which move the great bulk of the traffic in all territories. The Commission's answer to this point was twofold: There was no proof that the territorial commodity and exception rate levels in the South and West were lower; and, second, the Commission could not revise every rate in the United States in one proceeding, and had a right to proceed step by step, with the class rates, which are the pattern for all rates, as the necessary and logical first step. Of a similar situation, where the Commission had undertaken, step by step, to correct a type of discrimination found illegal, the Supreme Court had said, in United States v. Wabash Railroad Company:

... The suppression of abuses resulting from violations of $\$ 6(7)$ would be rendered practically impossible if the Commission were required to suppress all simultaneously or none. Section I2(I) imposes on the Commission the duty to enforce the provisions of the Act. That duty under $\$ 6(7)$ would hardly be performed if the Commission were to decline to enforce it against one because it could not at the same time enforce it against all. ${ }^{43}$

\section{Interterritorial rate problems are insoluble without uniformity in class ratings} and rates.

On a physical basis, the railroads of the United States have developed into a national system. Carloads of freight loaded at any point can be delivered to any other point where standard-gauge railroads exist without unloading and reloading en route. However, the uniformity that characterizes this mechanical service does not extend to freight rates, the price of the service. Consequently, there exists a

\footnotetext{
12 321 U. S. 403, 414 (I944).
} 
composite of regional rate structures that do not and cannot be made to fit together properly, because of pronounced differences in both the level and scheme of the rates. This regionalism restricts commerce and trade by hampering a national flow of traffic across these territorial boundary lines, thus retarding economic progress. As stated by the late Joseph B. Eastman, in his first report to Congress as Federal Coordinator of Transportation:

... An objectionable phase of the railroad situation for many years has been the maintenance of regional differences and distinctions, which are very imperfectly related to differences in costs and of territorial boundary lines ("Chinese walls") where rate systems and practices change. It has tended to provincialize the railroads and discourage national unity of action. It has been a prolific source of complaints to the Commission. ${ }^{44}$

The malignant effects of territorial rate discriminations were noted by the Supreme Court in Georgia v. The Pennsylvania Railroad Company:

... Discriminatory rates are but one form of trade barriers. They may cause a blight no less serious than the spread of noxious gas over the land or the deposit of sewage in the streams. They may affect the prosperity and welfare of a State as profoundly as any diversion of waters from the rivers. They may stifle, impede, or cripple old industries and prevent the establishment of new ones. They may arrest the development of a State or put it at a decided disadvantage in competitive markets. ${ }^{45}$

\section{The Atrack on the Commission's Decision}

\section{A. Procedure}

The Urgent Deficiencies Act of $1913^{46}$ gives the district courts of the United States original jurisdiction of cases brought to enjoin, set aside, annul, or suspend, in whole or in part, any order of the Interstate Commerce Commission. The venue of such suits is governed by section $43,{ }^{47}$ and procedure by sections $44-48,{ }^{48}$ which provide, among other things, that such suits shall be brought against the United States, with intervention by the Interstate Commerce Commission a matter of right. The jurisdiction of the District Court for the Northern District of New York in the Class Rate case rested on these provisions. The interlocutory injunction of the District Court was issued under section 47. After the court entered its final decree, the plaintiffs below took a direct appeal to the Supreme Court of the United States, as provided for in section 47 .

\section{B. Scope of Review}

The scope of review by a district court and by the Supreme Court of orders of the Interstate Commerce Commission, when such orders are attacked under the procedure used in the Class Rate case, is narrow and closely circumscribed under the Supreme Court's decisions.

\footnotetext{
"SEN. Doc. No. I19, 73d Cong., 2nd Sess. 29 (1934).

s6 324 U. S. 439,450 (I944).

${ }^{19} 38$ STAT. 219 (r9r3), 28 U. S. C. \$3I (r940).

1738 STAT. 219 (I913), 28 U. S. C. $\$ 43$ (I940).

${ }^{48} 38$ STAT. 220 (I9I3), 28 U. S. C. $\$ \$ 44-48$ (1940).
} 
The doctrine of administrative finality ${ }^{48}$ is especially applicable to rate cases, the technical complexity of which prohibits judicial inquiry on the merits:

The process of rate making is essentially empiric. The stuff of the process is fluid and changing - the resultant of factors that must be valued as well as weighed. Congress has therefore delegated the enforcement of transportation policy to a permanent expert body and has charged it with the duty of being responsive to the dynamic character of transportation problems. Cf. Railroad Commission v. Rowan \& Nichols Oil Co., 3 ro U. S. $573,58 \mathrm{I}-82$.

The wisdom of the narrow scope within which Congress has confined judicial participation in the rate-making process is strikingly vindicated by the history of this controversy.... There was no ready answer either in law reports or in economic experience. Any solution had to rest on informed judgment. And judgment in a situation like this implies, ultimately, prophecy based on the facts in the record as illumined by the seasoned wisdom of the expert body. In this perspective, the Commission had several choices before it-but all inevitably rested upon trial and error.... Of only one thing could the Commission be completely certain: no action could be taken without "adversely affecting certain of the conflicting interests." I64 I.C.C. $6 \mathrm{x}_{9}, 698 . \ldots$ That the Commission itself was of divided mind in the successive stages of this controversy emphasizes that the problem is enmeshed in difficult judgments of economic and transportation policy. Neither rule of thumb, nor formula, nor general principles provide a ready answer. We certainly have neither technical competence nor legal authority to pronounce upon the wisdom of the course taken by the Commission. It is not for us to tinker with so sensitive an organism as the grain rate structure, only a minor phase of which is caught in the record before us. If we were to grant the relief sought by the appellants, we would be restoring evils which the exclusive rate-break adjustment was designed to remove-evils which, for all we know, would be far more serious than those complained of by the appellants. ${ }^{50}$

Some economic problems are so difficult of solution that it is unfortunate that they have to be decided at all. However, when they are presented some solution must be found, even though it may not be, and may not purport to be, the only possible solution; and where a rate problem of this kind is presented, Congress and the Supreme Court have left no doubt that it is the Commission, and not the courts, which must make the decision and have the last say under the doctrine of administrative finality, subject only to those few well-defined and closely restricted lines of inquiry which the reviewing court may take:

... the Commission's order does not become suspect by reason of the fact that it is challenged. It is the product of expert judgment which carries a presumption of validity. And he who would upset the rate order under the Act carries the heavy burden of making a convincing showing that it is invalid because it is unjust and unreasonable in its consequences. Federal Power Commission v. Hope Natural Gas Co., 320 U. S. 59r, 602. The Commission considered that it had, and we find no reason to doubt that it had, the evidence before it that was needful to the discharge of its duty to the public and to the regulated railroad. "With that sort of evidence before them, rate experts of acknowledged ability and fairness, and each acting independently of the other, may not have reached identically the same conclusions. We do not know whether the results would have been approximately the same. For there is no possibility of solving the question as though it

${ }^{10}$ Rochester Telephone Corp. v. United States, 307 U. S. 125 (I939).

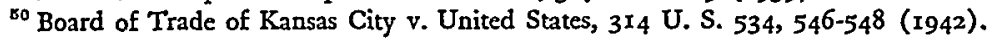


were a mathematical problem to which there could only be one correct answer. Still there was in this mass of facts that out of which experts could have named a rate. The law makes the Commission's finding on such facts conclusive." Interstate Commerce Commission v. Union Pacific R. Co., 222 U. S. 54I, 550. ${ }^{.1}$

\section{Other Legal Questions}

It has already been pointed out that the two principal legal issues in the Class Rate case were the illusory issue of the effect of the Transportation Act of 1940, and particularly the amendment to section 3(I) of the Interstate Commerce Act, on the power of the Commission to remove territorial discriminations, and the further central issue of whether the report and order of the Commission were supported by adequate evidence and had a rational basis, i.e., the issue of arbitrariness. There were, however, other legal questions which will be briefly touched upon below.

I. Common source of discrimination and alternative remedy-the Texas \& Pacific case.

The appellants, largely on the basis of Texas \& Pacific Railway Co. v. United States, contended that the Commission erred in not giving the carriers a choice between alternative methods of removing the rate discriminations, and they maintained, further, that the Commission had no power to order discriminations removed because different carriers were involved in the two sets of rates. These contentions are based on the following language from the Texas \& Pacific case:

A carrier or group of carriers must be the common source of the discrimination, must effectively participate in both rates, if an order for the correction of the disparity is to run against it or them. Where an order is made under $\S_{3}$ an alternative must be afforded. The offender or offenders may abate the discrimination by raising one rate, lowering the other, or altering both. ${ }^{52}$

The answer to the alternative remedy point is that the order in the Class Rate case was not made under section $3^{53}$ but under section ${ }^{5}(\mathrm{I})^{54}$ of the Act. Mr. Justice Roberts pointed out, both in the Texas $\mathcal{E}$ Pacific case and in Youngstoun Sheet $\&$ Tube Company $v$. United States, ${ }^{55}$ that the alternative remedy doctrine does not apply to orders under section ${ }_{5}(\mathrm{r})$.

To the contention that the same carriers must control both sets of rates, the answer is that the only rate relationship found by the Commission to be discriminatory was the relationship between the class rates from other territories into official territory on the one hand, and the rates within official territory on the other hand, both sets of which are controlled by the official-territory carriers, which make the latter rates and jointly control the former (interterritorial) rates. It is well settled that it is not necessary that a carrier's rails reach the point subjected to prejudice for it to be guilty of violating section $3(x) .^{56}$

'1 Interstate Commerce Commission v. City of Jersey City, 322 U. S. 503, 512-513 (1944).

5289 U. S. 627,650 (1933).

${ }^{53} 24$ STAT. $3^{80}$ (I887), as amended, 49 U. S. C. $\$ 3$ (I940).

${ }^{5} 24$ Stat. 384 (r887), as amended, 49 U. S. C. $\$ 15$ (r) (r940).

${ }^{26} 295$ U. S. 476 (1935).

${ }^{50}$ St. Louis Southwestern Ry. v. United States, 245 U. S. 136, at 144 (1917); Chicago, I. \& L. Ry. v. United States, 270 U. S. 287 (1926). 
Finally, serious doubts are cast on the validity of the reasoning in the Texas \& Pacific case by the dissenting opinion of Mr. Justice Stone, concurred in by Chief Justice Hughes, Mr. Justice Brandeis, and Mr. Justice Cordozo, in which sharp issue is taken with the majority on the issues of the necessity of alternative remedies and a common source of discrimination. After pointing out the fallacies in the majority opinion, the minority reached the conclusion that the situation in the Texas \& Pacific case was identical with that in the St. Louis Southwestern case. ${ }^{57}$

Of course, all of the cases referred to above were decided before the 1940 amendment of section $3(\mathrm{r})$. The effect of that amendment on the question whether there can be a discrimination between territories, not involving the same groups of carriers, which the Commission is, by the amendment, given power to correct, even though neither carrier is by itself guilty of an unlawful discrimination, has not been before the Supreme Court, and is not before the Court in the Class Rate case. There is, however, a strong argument in favor of the existence of such power. The different rate territories, almost by definition, contain separate groups of carriers. If a Missouri shipper, competing in the Twin Cities with an Illinois shipper, must pay freight on the western scale in order to go up the west bank of the Mississippi River to Minneapolis, and suffer a 50 per cent higher freight rate than his competitor across the Mississippi River, who, using another carrier, is shipping on the official rate basis to St. Paul, and the Commission is powerless to correct this discrimination, there is still a serious void in the Commission's power, which was not corrected in 1940 by the addition of the word "territory" to section 3 (I) of the Act. Even before r940, the Supreme Court, in United States v. Chicago, Milwaukee, St. Paul \& Pacific Railway Company, said that the Commission under section 15 "may conduct a comprehensive inquiry into the rates of all the lines within the area in controversy, may fix the fair relation between one line and another, and may build the structure of the rates accordingly." If the power of the Commission is so narrow that it is precluded from protecting shippers against discrimination unless both rates involved in the rate relationship are controlled by the same carriers, the Commission will find that it is unable to build a rate structure from which discrimination between territories can fairly be said to be absent. Surely, this was not the intention of Congress in $19400^{59}$

\section{Preliminary findings.}

The appellants insisted that the Commission had failed to make a number of preliminary findings which they said were essential to support the ultimate findings. There was no unanimity among the appellants about the particular findings claimed to be necessary. The Government contended that a short answer to these contentions was that none of the findings asserted to be necessary was jurisdictional, and "the Commission is not compelled to annotate to each finding the evidence supporting it." $" 00$

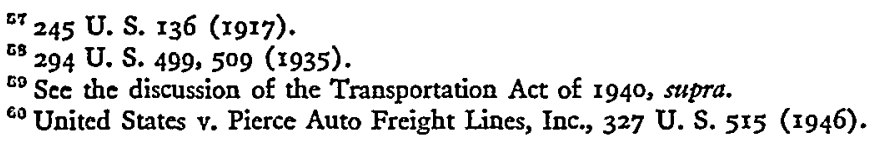


The principal preliminary finding which the appellants insisted was essential was a finding that the rates in official territory were non-compensatory. Such a finding, it was argued, was prerequisite to the order that these rates be raised Io per cent. However, where rates are discriminatory their compensatory character is not the decisive factor. ${ }^{81}$ Further, the rates in official territory were found by the Commission to be unreasonably low, in violation of section $\mathrm{I}$ of the Act, and such a finding may be proper even though the rates found unreasonable have been specifically found to be compensatory. ${ }^{62}$

\section{Confiscation.}

The western railroads, in their separate suit and by their intervention in the original action, alleged that the new less-carload rates in the West were shown to be confiscatory on the face of the Commission's report, because of the Commission's finding that the western less-carload rates, which the Commission ordered reduced by to per cent, resulted in 1939 in a deficit to the railroads of over thirty-four million dollars. In support of this allegation the western roads, over the objection of the Government, ${ }^{63}$ introduced additional testimony in the district court. The infirmities in this confiscation evidence, which the district court found not sufficiently convincing, ${ }^{64}$ are too technical to permit discussion in the space available here, but it might be pointed out that less-carload freight accounts for only a very small percentage of total railroad freight tonnage ( $\mathrm{I} .3$ per cent in 1944$) ;^{\text {65 }}$ unlike carload freight, the carriers load it, handle it, and unload it, and it is within their power to make this service expensive to themselves (for example, by light loading of cars) or to keep their costs down to a minimum (for example, by full loading of cars). If rates should be made with the idea of compensating carriers for the most expensive way of handling less-carload traffic, the inevitable result would be to reward inefficiency and to penalize shippers unnecessarily.

The Commission was trying to prescribe a rate structure to eliminate the complicated and chaotic hodgepodge that had grown up in the several rate territories. Isolated differences in costs are bound to exist between railroads and between particular segments of traffic. Although governmental authority cannot single out a particular segment of traffic and require railroads to carry it below cost, ${ }^{00}$ no rate structure can make every shipment on every mile of every particular road move at a profit. As Mr. Justice Hughes pointed out in the Northern Pacific case, "the ratemaking power may be exercised in a practical way and ... the legislature is not bound to assure a net profit from 'every mile, section, or other part into which the road may be divided." "\$ot The district court agreed with the Government that if a

${ }^{01}$ Interstate Commerce Commission v. Inland Waterways Corp., 319 U. S. 671 (1943).

${ }^{62}$ Scandrett v. United States, 32 F. Supp. 995 (I940), aff'd, 3 I2 U. S. 66I (I94I). See also Jefferson Island Salt Mining Co. v. United States, 6 F. 2d 315 (r925).

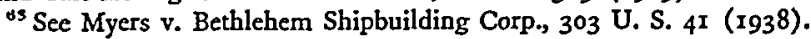

et 65 F. Supp. 856, 869 (1946).

o6 Interstate Commerce Commission, Statistics of Railways in the United States, 1944 (1946).

${ }^{c 0}$ Northern Pacific Ry. v. North Dakota, 236 U. S. 585 (1915).

${ }^{67}$ Id. at 600 . 
small fraction of the less-carload traffic might result in loss, this was an incidental and not a deliberate result, in a "mere detail" of a national rate structure, for which it would be improper to set aside the entire rate structure.

\section{ConcLusion}

The district court upheld the contentions of the Government all along the line. ${ }^{68}$ The district court adopted all of the Commission's findings of fact. While the interim order of the Commission did not bring about absolute equalization of class rates, and did not effect immediate classification uniformity, but only ordered the southern and western rates reduced to per cent and the official rates raised Io per cent, thus leaving these rates about ro per cent apart, the interim order was premised on the necessity of complete equalization and uniformity, which was delayed only to await the completion of the uniform classification. Thus the upholding of the Commission's order would place final approval on the result toward which the Commission is working-absolute classification and class-rate uniformity so long as differences in territorial transportation conditions are not substantial enough to warrant territorial differences in class rates.

The power of the Commission to correct all interterritorial freight rate discriminations thus seems clear, and no further legislation to that end appears either necessary or desirable. Certainly it would be unwise for Congress to require freight rate uniformity regardless of substantially differing transportation conditions in the territories.

There is only one qualification to this conclusion. It was suggested above that the Commission and the courts have not yet undertaken to pass on the issue of whether a discrimination can be corrected between intraterritorial rates of one territory and intraterritorial rates of another territory. However, for reasons stated above, it is believed that such power exists, and that the Commission could have gone farther than it did in its findings as to discrimination and its order in the Class Rate case.

This conclusion concerning the adequate power of the Commission is necessarily divorced from any opinion as to the ability of the Commission to combat railroad conspiracies which may violate the Sherman Antitrust Act. The Commission has all the power it needs to remove all interterritorial freight rate discriminations, and whether these discriminations stem from conspiracies, individual pressures, lack of information about transportation conditions, or inertia is irrelevant to the question of the power of the Commission to remove them. The Commission in the Class Rate case has already shown its disposition to remove these discriminations, and the question of conspiracy or monopoly as the source of the discrimination was not and could not properly have been considered by the Commission in making its inquiry

on 65 F. Supp. 856 (1946). 
and determination. The Commission has no jurisdiction to act on antitrust conspiracies as such. The courts have no jurisdiction to make new rates to eliminate the effects of antitrust conspiracies. The power of the Commission and the power of the courts in connection with interterritorial freight rate discriminations are therefore wholly separate and unrelated powers. The power of the Commission is the power to correct rates; the power of the courts is the power to enjoin or punish conspiracies. 